\title{
Back-analysis of in-pit dump slope failure and remediation results at Bara Anugrah Sejahtera open pit coal mine, Indonesia
}

\author{
L Rachmad GEOMINE Mining and Geotechnical Consultant, Indonesia \\ D Aryanda GEOMINE Mining and Geotechnical Consultant, Indonesia \\ M Daroji Titan Group, Indonesia
}

\begin{abstract}
Bara Anugrah Sejahtera (BAS) Mine experienced a massive slope movement during the building of its overburden in-pit dump. The total material affected by this movement was around $47,000 \mathrm{~m}^{3}$ and covering an area of $10,000 \mathrm{~m}^{2}$. This movement created not only in-pit dump failure but also floor heaving along the highwall. The failure stopped the mining operation for about 12 months, and during that period, geology and geotechnical investigation was carried on.

In Indonesia, the practice of overburden in an in-pit dump is typical due to the limitation of 'free and already compensated' land inside the mining permit boundary for placing the out-pit dump. Another reason is the requirements for getting forestry permits for other nominated out-pit dump areas. Conventionally, an in-pit dump is carried out in one part of the pit walls (sidewall or highwall) that has reached its final geometry state. The finalised pit wall is used as a buttress so that the condition of stability can be maintained. For the BAS case, the final position of the pit is still going to happen in a few years, while the area for the out-pit dump is limited. Therefore, the BAS mine in-pit dump has to be placed without buttressing to any finalised pit wall.

From detailed investigation, the existence of the montmorillonite clay layer below the pit floor and a geological structure along the strike of the pit were suspected to be the leading causes of the movement and heaving. Back analyses were carried out to validate material properties by comparing actual and modelling conditions. Models were also used to determine the most appropriate remediation strategy from geotechnical, operational, and financial perspectives. BAS has implemented the selected remediation strategy with success.

This paper discusses the back-analysis to estimate montmorillonite and structure properties. Also, it explains the evaluation of several remediation options using those properties, the implementation of the selected option, and its current results.
\end{abstract}

Keywords: back-analysis, in-pit dump, slope failure

\section{Introduction}

Coal mining operation at the Bara Anugrah Sejahtera (BAS) mine, located in South Sumatra, has been carried out by strip mining with several coal seams as production operations targets. As part of the strip mining cycle, overburden (OB) and/or interburden (IB) material need to be excavated before coal seams are exposed. After being excavated, the OB material will be placed in a location known by several terms: waste dump, disposal, or overburden dump.

At the beginning of pit mining, disposal could be placed outside the pit area, known as an out-pit dump. As the pit grows and part of the pit area is being mined out, there is an opportunity to place the OB material in the pit area, known as an in-pit dump. In addition to reducing operating costs for hauling of OB material, this in-pit dump strategy can also reduce the area of impacted land that needs to be acquired for $O B$ placement. Another advantage is from the environmental point of view where the existence of the pit void can be reduced. The BAS mine was in the process of implementing an in-pit OB placement operation when it 
discovered cracks and material movement in June 2015. From the investigation, it was indicated that the movement may be related to the montmorillonite layer located under the pit floor. This mineral, when exposed to water, will change its character or properties. Montmorillonite is the main composition for clay minerals in sediments and is a suspended material. Sedimentary rocks containing montmorillonite clay are good adsorbents (Saeedi et al. 2013; Zhang et al. 2014). When the slope is encumbered with dump material, the material moves along the bedding.

The best method to evaluate the stability of the in-pit dump is to do a back-analysis of the rock mechanics properties (Hawley \& Cunning 2017). The mechanical properties of the materials in the in-pit dump were analysed to replicate the actual conditions of BAS. In the back-analysis, the geomechanical properties analysed are Young's modulus (E), Poisson's ratio $(V)$, cohesion $(C)$, internal friction angle $(\phi)$, permeability $(\mu)$ and even the initial state of stress (Sakurai 2017).

This paper will discuss the investigation of the dump movement, the back-analysis of the mechanical properties of montmorillonite and geological fault, the evaluation for alternative remediation, the implementation of the remediation strategy, and current results.

\section{Stability issues}

On 14 June 2015, several cracks, dump material movement, and floor heave were identified in the pit area of the BAS mine. The movement and cracking occurred on the up-dip side of a geological structure, which extends from the north-northeast to the south-southwest direction (Figure 1). This structure acted as a barrier to the material that moved from the lowwall to the highwall direction. The initial investigation indicated that the presence of a weak montmorillonite layer could influence this movement. This layer acted as a slip plane.

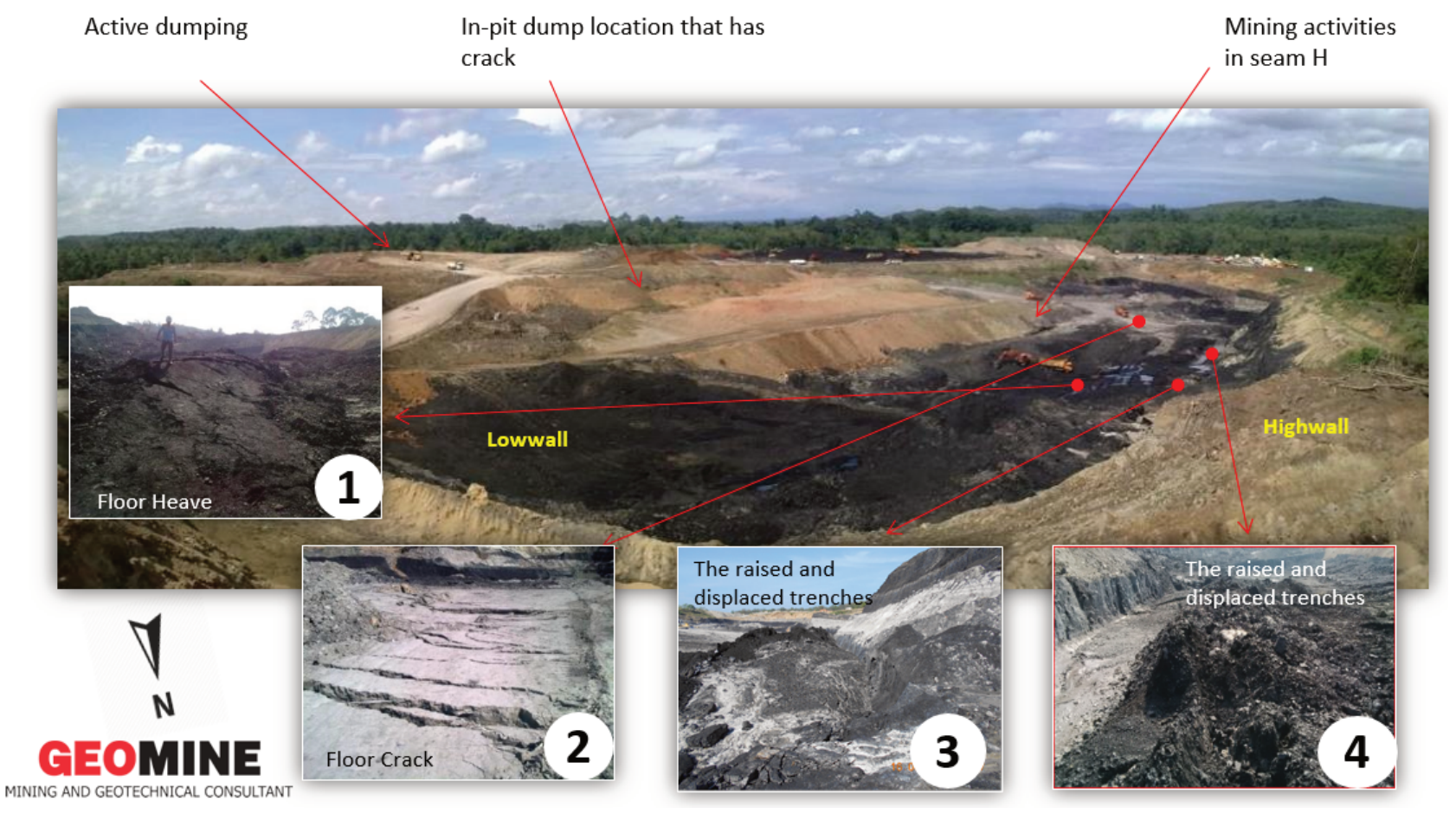

Figure 1 Pit Bara Anugrah Sejahtera situation (June 2015)

The mine requested further analysis be conducted to determine the cause of this movement and also to develop a remediation strategy. 


\section{$3 \quad$ Initial material properties}

Before a proper geotechnical model could be used to analyse the BAS in-pit dump remediation strategy, the properties of the materials in the BAS pit need to be determined (Table 1). The residual direct shear test could provide some of these materials (sandstone, claystone, siltstone, and coal) properties estimation. The in-pit dump material properties are estimated based on cohesion and internal friction angle for the unsaturated shear strength parameters using waste dump properties approach from Simmons \& McManus (2004).

Table 1 Initial material properties for BAS in-pit dump failure analysis

\begin{tabular}{|c|c|c|c|c|}
\hline Domain & $\begin{array}{l}\text { Density } \\
\left(t / \mathrm{m}^{3}\right)\end{array}$ & $\begin{array}{l}\text { Cohesion } \\
(\mathrm{kPa})\end{array}$ & $\begin{array}{l}\text { Friction } \\
\text { angle }\left({ }^{\circ}\right)\end{array}$ & Remarks \\
\hline Sandstone & 1.88 & 96 & 35 & $\begin{array}{l}\text { Density from lab test, } C \text { and } \phi \text { from triaxial } \\
\text { test, UCS test, GSI and rocklab }\end{array}$ \\
\hline Claystone & 1.89 & 65 & 11 & $\begin{array}{l}\text { Density from lab test, } C \text { and } \phi \text { from direct } \\
\text { shear residual test }\end{array}$ \\
\hline Siltstone & 1.81 & 137 & 12 & $\begin{array}{l}\text { Density from lab test, } C \text { and } \phi \text { from direct } \\
\text { shear residual test }\end{array}$ \\
\hline Fault & 1.80 & $10-20$ & $5-15$ & Assumption \\
\hline Montmorillonite clay & 1.80 & 5 & $0-28$ & Assumption \\
\hline Waste dump material & 1.80 & 20 & 25 & Simmons \& McManus (2004) \\
\hline Alluvial/weathered & 1.80 & 11 & 24 & Similar material properties in other project \\
\hline Coal & 1.23 & 240 & 34 & $\begin{array}{l}\text { Density from lab test, } C \text { and } \phi \text { from triaxial } \\
\text { test }\end{array}$ \\
\hline
\end{tabular}

The above approach leaves two materials that need to be back-analysed to get the appropriate properties of the actual conditions; namely for montmorillonite clay material and the structure material.

\section{$4 \quad$ Back-analysis for in-pit dump failure}

Figure 2 shows the definition of back-analysis according to Sakurai (2017). In the back-analysis, input data are measured values such as displacement, stress, and strain, while the output results are mechanical parameters of rock mass such as Young's modulus, Poisson's ratio, strength parameters (cohesion and internal friction angle). This procedure is a reverse calculation from ordinary analysis, which is why it is called 'back-analysis' (Sakurai 2017).

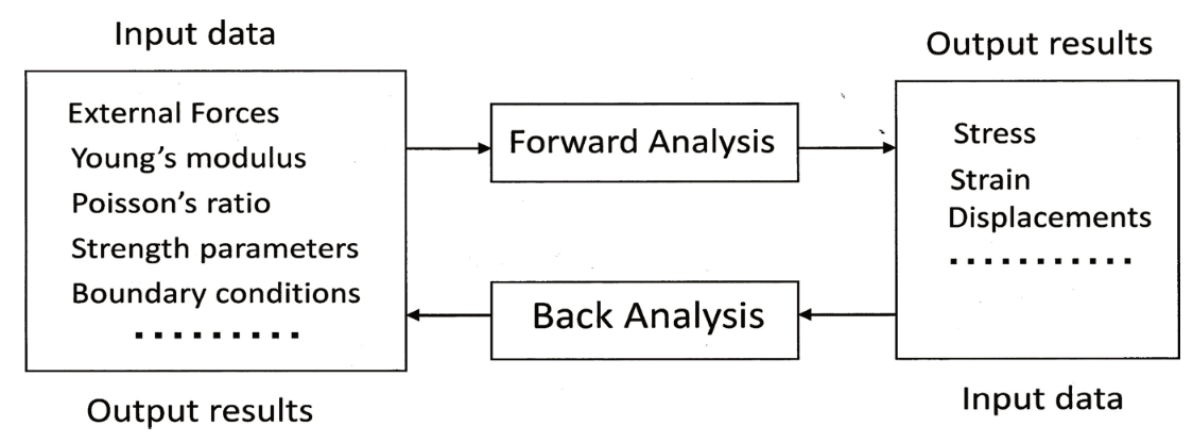

Figure 2 Definition of back-analysis (Sakurai 2017) 
The BAS back-analysis used section 2 and section 4 (Figure 3) because of their proximity to the area of material movement. Back-analysis was carried out in three stages:

1. May 2015: Before the cracks occurred, in-pit dump had begun to be placed on the up-dip side of the lowwall, mining seam $\mathrm{H}$ coal had not started, and the pit slope conditions were stable.

2. June 2015: The cracks had occurred, mining seam $\mathrm{H}$ coal had initiated, and the pit slope condition was unstable.

3. November 2016: The dump movement continued but at a slower rate and the pit slope was in a relatively stable state.

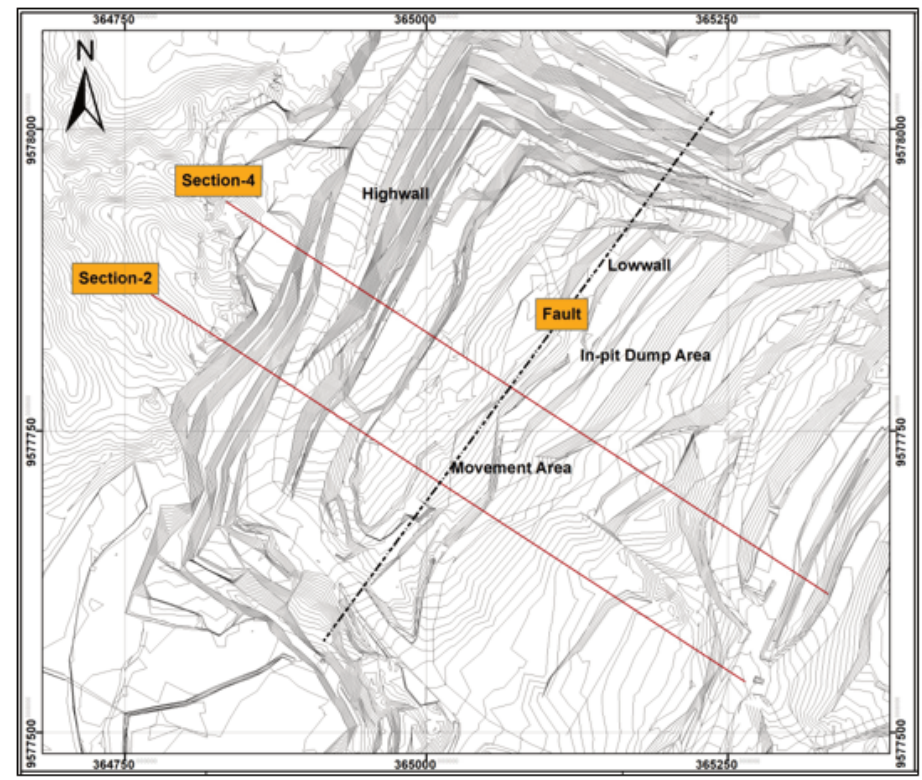

Plan View

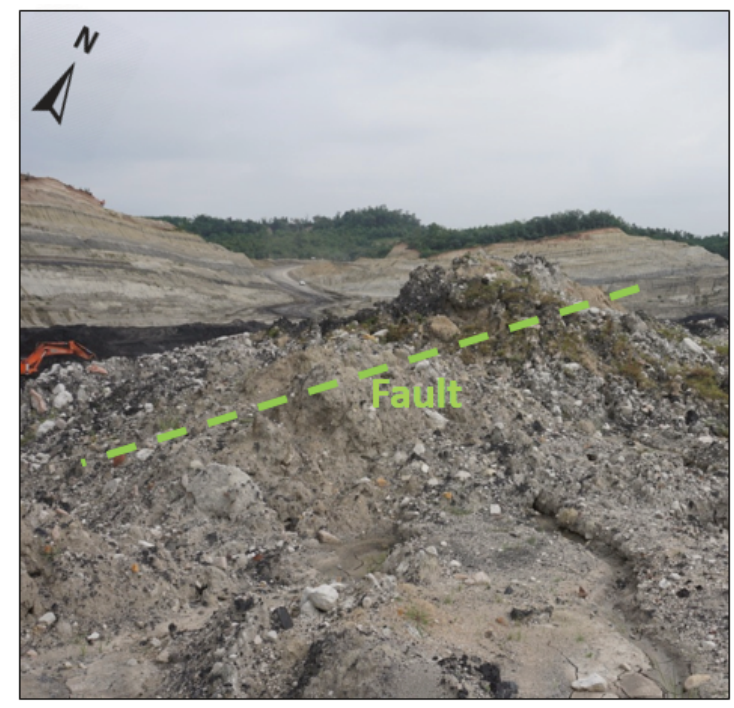

Oblique View

\section{Figure 3 Plan view and oblique view section}

Analysis was carried out using the limit equilibrium method, with the final result being the value of the slope Factor of Safety (FoS). A FoS is generally estimated using the limit equilibrium method, and the parameters evaluated for the back-analysis procedure are cohesion and internal friction angle (Sakurai et al. 2009). The limit equilibrium method consists of cutting the slope into small pieces. The direction of the force acting on each slice on the slope is assumed, and the equilibrium of forces and moments exists and is considered (Liu et al. 2015; Memon 2018). 
The limit equilibrium analysis can use several methods (Table 2), namely Bishop, Fellenius, Janbu, Spencer, Sarma (Duncan \& Wright 2005). In this analysis, the method used is the Sarma method. This method is selected because it considers the equilibrium parameters in full and considers the interslice force factor. The Sarma method is suitable for non-circular slip surfaces, especially for non-vertical cut edges (Chaulya \& Prasad 2016; Duncan \& Wright 2005). Table 2 shows the use of slope stability analysis methods.

Table 2 Procedure for slope stability analysis with limit equilibrium and their use (Duncan \& Wright 2005)

\begin{tabular}{ll}
\hline Procedure & Use \\
\hline Fellenius & $\begin{array}{l}\text { Applicable to non-homogeneous slopes and C and } \phi \text { materials where slip surface can be } \\
\text { approximated by a circle. Very convenient for hand calculations. Inaccurate for effective } \\
\text { stress analysis with porewater pressures. }\end{array}$ \\
$\begin{array}{ll}\text { Bishop } \\
\text { simplified }\end{array}$ & $\begin{array}{l}\text { Applicable to non-homogeneous slopes and C and } \phi \text { materials where slip surface can be } \\
\text { approximated by a circle. More accurate than Ordinary Method of slices, especially for } \\
\text { analysis with high pore pressures. Calculations feasible by hand or spreadsheet. }\end{array}$ \\
$\begin{array}{l}\text { Janbu } \\
\text { simplified }\end{array}$ & $\begin{array}{l}\text { Applicable to non-circular slip surfaces. Also for shallow, long planar failure surfaces that } \\
\text { are non-parallel to the ground surface. }\end{array}$ \\
Morgenstern- & $\begin{array}{l}\text { An accurate procedure applicable to virtually all slope geometries and material profiles. The } \\
\text { simplest complete equilibrium procedure for computing Factor of Safety. }\end{array}$ \\
Price & $\begin{array}{l}\text { Rigorous, well-established complete equilibrium procedure. } \\
\text { Surma }\end{array}$
\end{tabular}

Back-analysis was conducted using the surveyed situation of the BAS pit in May 2015, June 2015, and November 2016. Groundwater level was modelled based on observation and monitoring data from each month's case. In May 2015, there were no cracks or movements yet in the dump material. The slope was still in a stable condition (Figures 4 and 7). In June 2015, cracks, dump material movement, and floor heave were identified (Figures 5 and 8). In November 2016, dump movement was still present, but the slope condition was relatively stable (Figures 6 and 9). Through trial and error process, montmorillonite and structure properties were determined, such that they gave stable conditions in May 2015 models, unstable conditions in June 2015 models, and marginally stable conditions in November 2016 models.

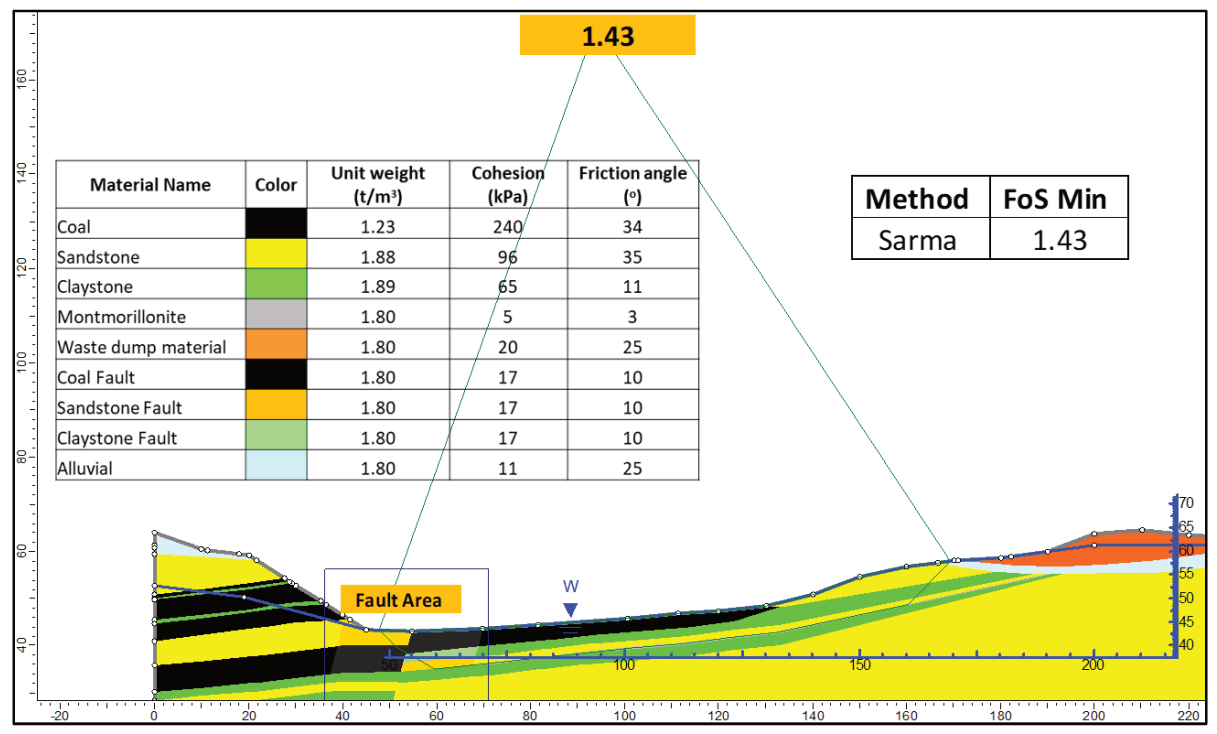

Figure 4 Back-analysis for section 2 (May 2015) 


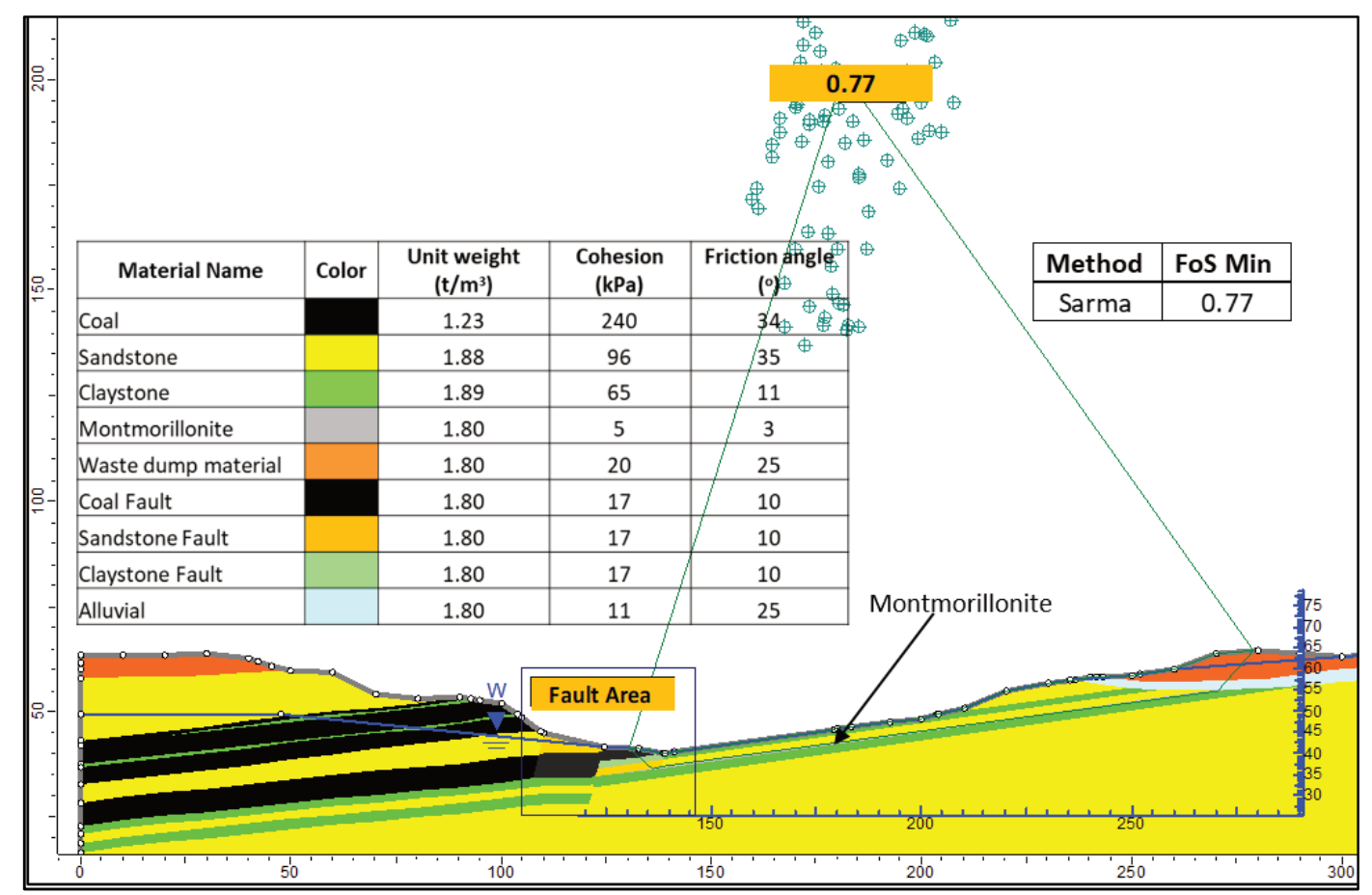

Figure 5 Back-analysis for section 2 (June 2015)

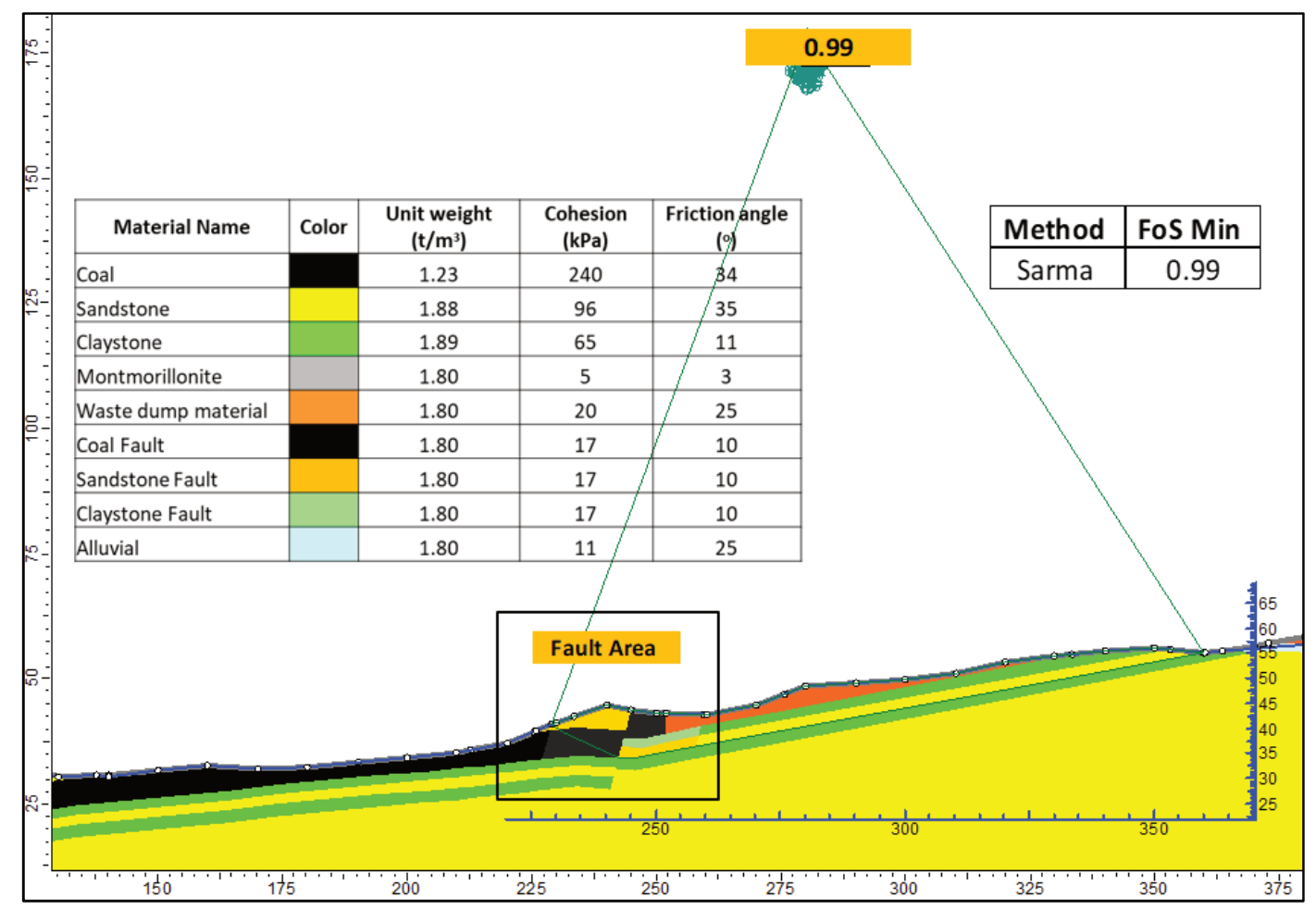

Figure 6 Back-analysis for section 2 (November 2016) 


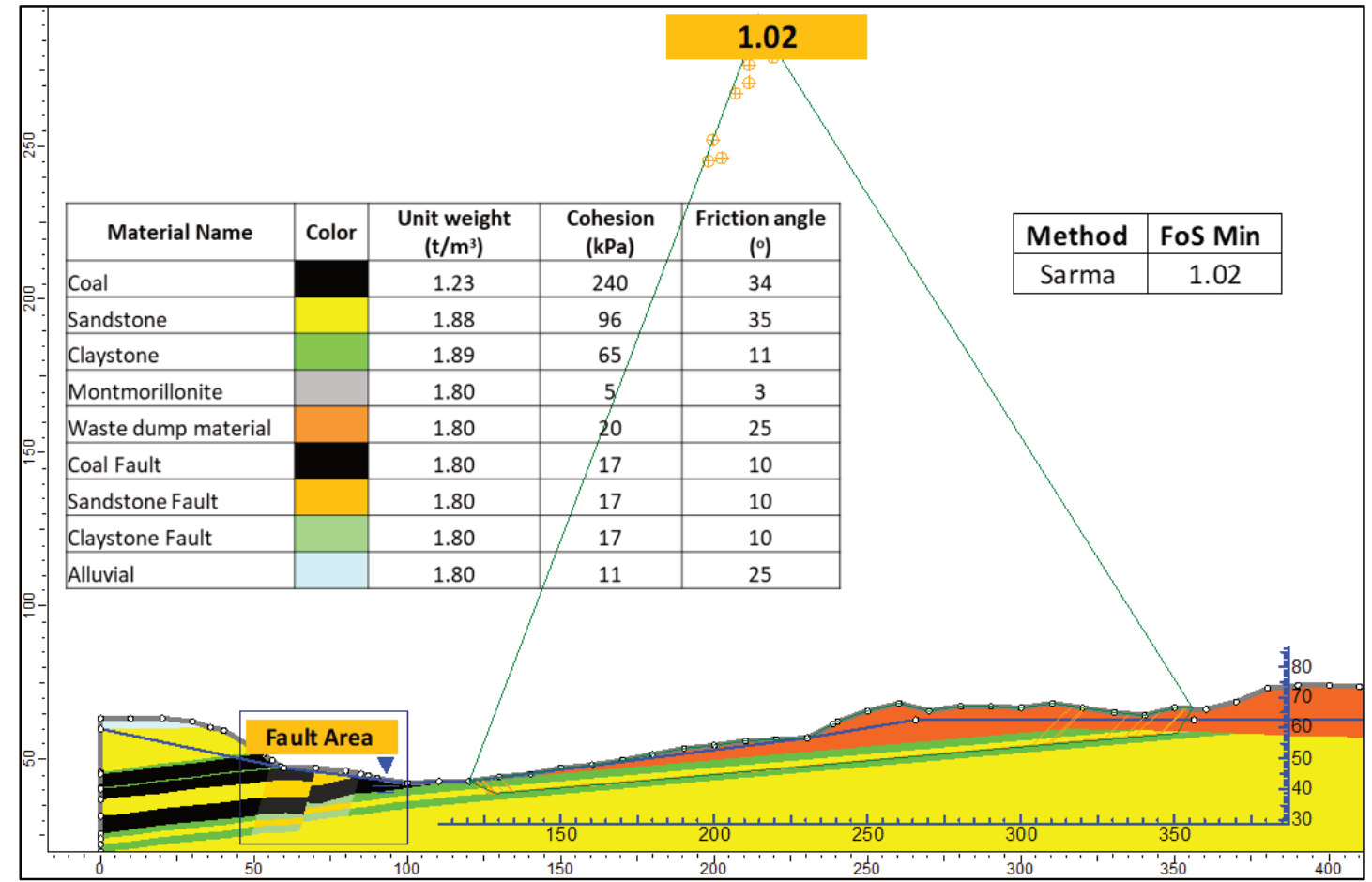

Figure 7 Back-analysis for section 4 (May 2015)

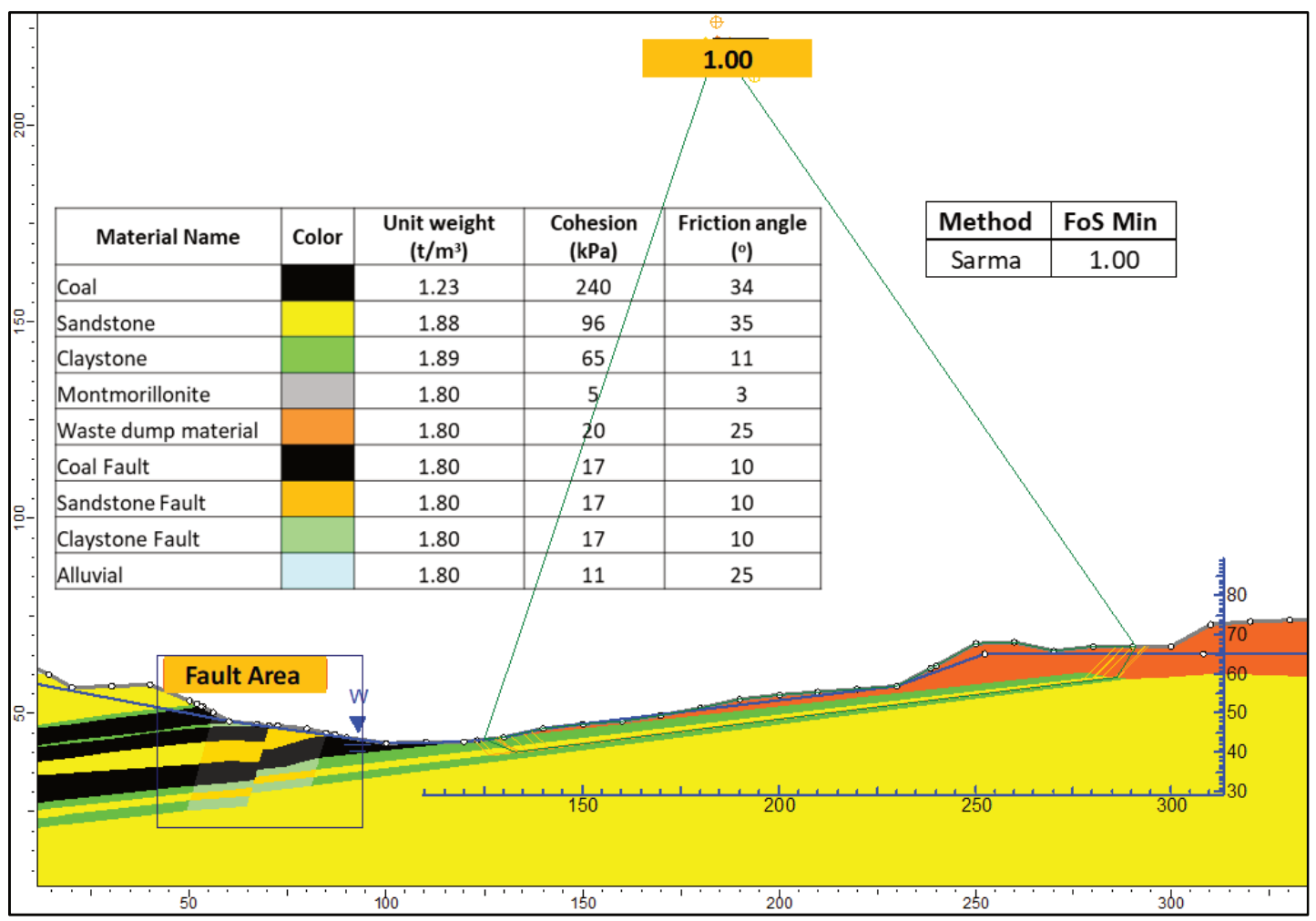

Figure 8 Back-analysis for section 4 (June 2015) 


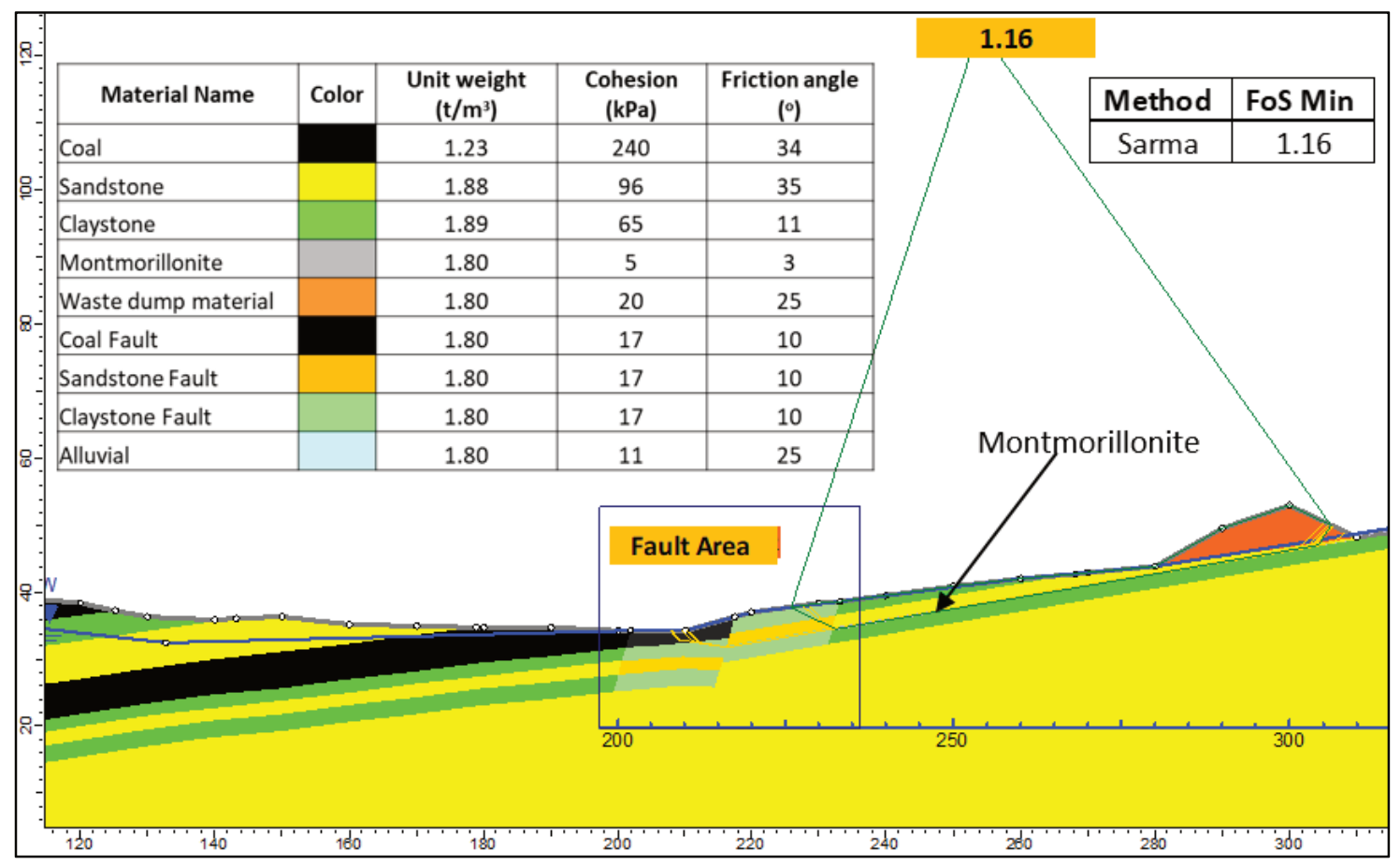

Figure 9 Back-analysis for section 4 (November 2016)

The back-analysis determined appropriate montmorillonite clay and fault properties for the models. Table 3 shows all the material properties of the back-analysis for the evaluation of BAS in-pit dump remediation strategy.

Table 3 Material properties from back-analysis

\begin{tabular}{llll}
\hline Domain & Density $\left(\mathrm{t} / \mathrm{m}^{3}\right)$ & Cohesion $(\mathrm{kPa})$ & Friction angle $\left(^{\circ}\right)$ \\
\hline Fault & 1.80 & 17 & 10 \\
Montmorillonite clay & 1.80 & 5 & 3 \\
\hline
\end{tabular}

\section{$5 \quad$ Evaluation of in-pit dump failure remediation options}

The in-pit dump strategy considered several remediation options for evaluation.

1. Option 1: Flattening overall in-pit dump slope angle from current design $\left(21^{\circ}\right)$, without removing montmorillonite and without counterweight construction.

2. Option 2: Unloading all floor materials to below the montmorillonite layer level and starting in-pit dump.

3. Option 3: Unloading only portions of the floor materials below structure and replacing them with selected waste material before continuing in-pit dump.

4. Option 4: Building counterweight construction to depths below the montmorillonite layer with coarse material before continuing in-pit dump.

Tables 4 and 5 show the results of stability analysis for those options. Option 1 only slightly improves the condition but the unstable condition still exists. Option 2 could improve the in-pit dump stability, however, this option is not economical. Option 4 could enhance the stability, but the slope needs to be very flat. Option 3 gives only a marginally stable condition but this option satisfies the operational and financial aspects. This option was selected to be the remediation strategy. 
Table 4 Results of alternative in-pit dump analysis for section 2

\begin{tabular}{lllll}
\hline Option & Description & $\begin{array}{l}\text { In-pit dump } \\
\text { slope angle }\end{array}$ & $\begin{array}{l}\text { Factor of } \\
\text { Safety }\end{array}$ & Remarks \\
\hline 1 & $\begin{array}{l}\text { Flattening overall in-pit dump } \\
\text { slope angle }\end{array}$ & 13 & 0.79 & $\begin{array}{l}\text { Slip along montmorillonite } \\
\text { (unstable) }\end{array}$ \\
\hline $\begin{array}{l}\text { Unloading all materials below } \\
\text { the montmorillonite layer }\end{array}$ & 13 & 1.45 & Stable \\
$\begin{array}{l}\text { Unloading portions of the } \\
\text { montmorillonite layer and } \\
\text { replacing them with selected } \\
\text { waste material }\end{array}$ & 13 & 1.15 & Marginally stable \\
\hline
\end{tabular}

Table 5 Results of alternative in-pit dump analysis for section 4

\begin{tabular}{lllll}
\hline Option & Description & $\begin{array}{l}\text { In-pit dump } \\
\text { slope angle }\end{array}$ & $\begin{array}{l}\text { Factor of } \\
\text { Safety }\end{array}$ & Remarks \\
\hline 1 & $\begin{array}{l}\text { Flattening overall in-pit dump } \\
\text { slope angle }\end{array}$ & 16 & 0.60 & $\begin{array}{l}\text { Slip along montmorillonite } \\
\text { (unstable) }\end{array}$ \\
\hline $\begin{array}{l}\text { Unloading all materials below } \\
\text { the montmorillonite layer }\end{array}$ & 16 & 1.34 & Stable \\
\hline $\begin{array}{l}\text { Unloading portions of the } \\
\text { montmorillonite layer and } \\
\text { replacing them with selected } \\
\text { waste material }\end{array}$ & 21 & 0.96 & Marginally stable \\
\hline & $\begin{array}{l}\text { Building counterweight using } \\
\text { coarse material }\end{array}$ & 9 & 1.12 & Marginally stable \\
\hline
\end{tabular}

In Option 3, some montmorillonite material is removed and then replaced with waste material. This option is considered effective enough to be implemented (Figure 10).

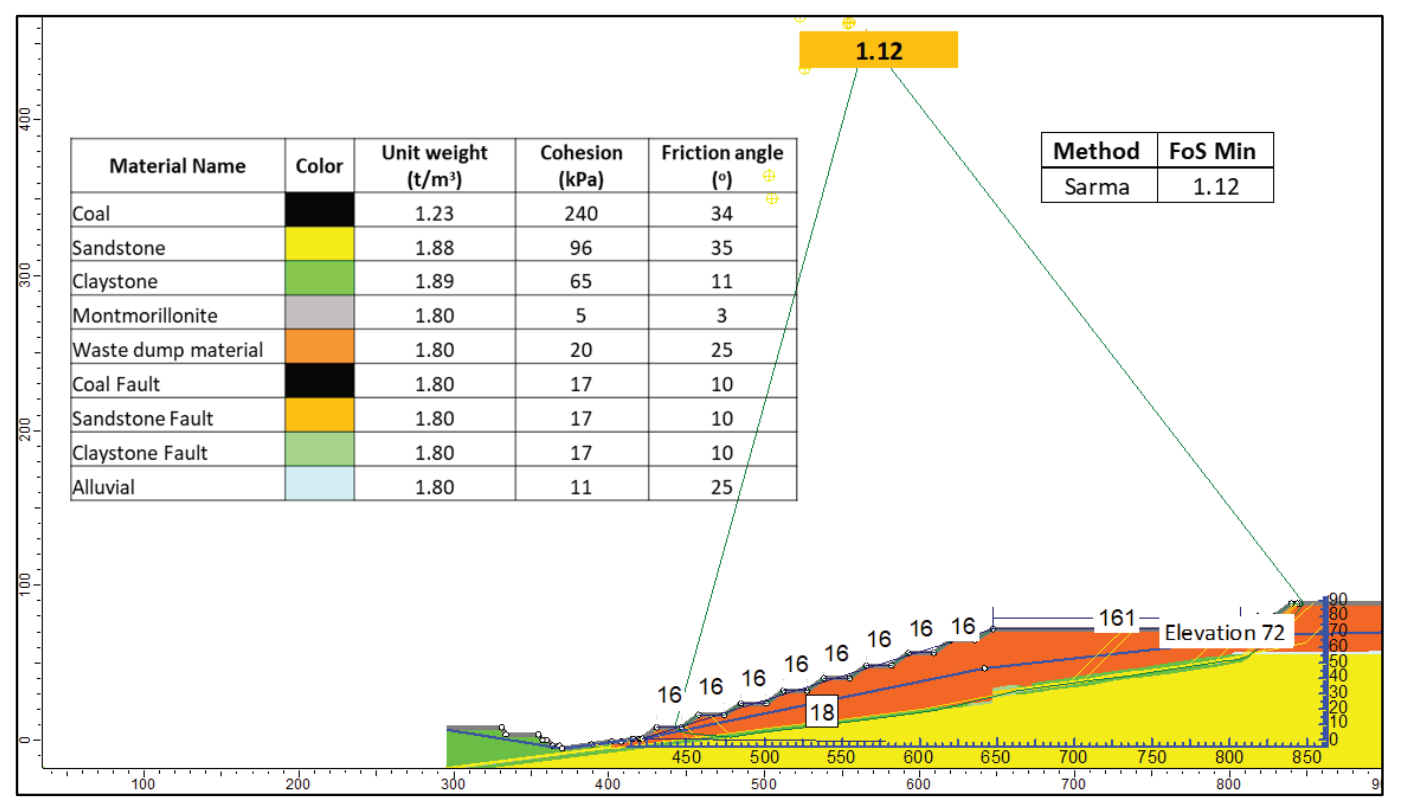

Figure 10 Result of stability analysis for Option 3 for section 4 
At present, BAS has implemented Option 3 for in-pit dump remediation with success, as shown in Figure 11. Routine visual observation and prism monitoring give no sign of further significant movements.

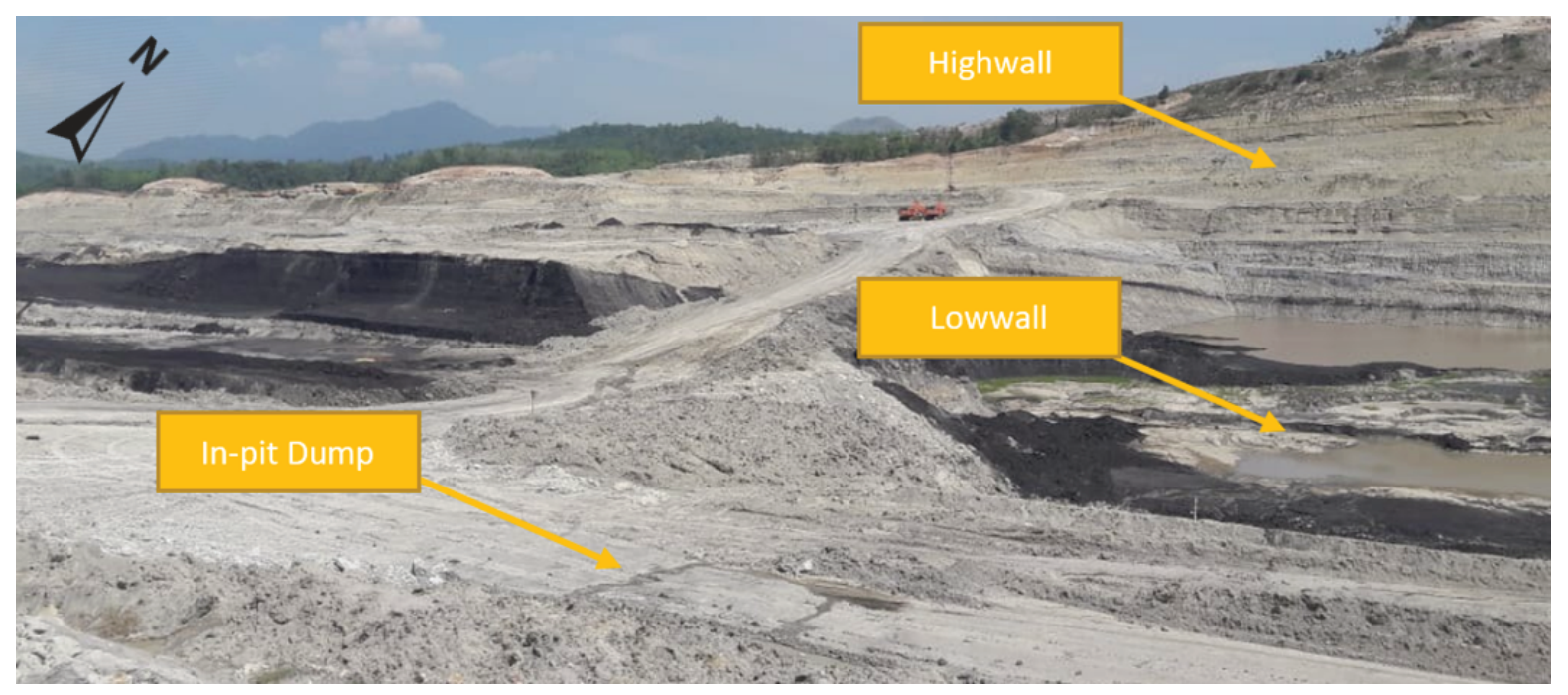

Figure 11 Current situation of in-pit dump Bara Anugrah Sejahtera (August 2019)

\section{Conclusion}

The presence of a montmorillonite layer under the coal seam and a geological structure influenced the BAS in-pit dump failures. The back analyses were performed to determine appropriate montmorillonite and structure properties. Evaluation of several remediation options using these properties resulted in selecting Option 3 (unloading only portions of the floor materials below structure and replacing them with selected waste material). BAS has implemented this option with success to the point that there are no further significant movements recorded.

\section{Acknowledgement}

The authors acknowledge permission from PT BAS for publication of this work. Also, we would like to express our thanks and appreciation to PT BAS staff for providing help and completing data during the study.

\section{References}

Chaulya, SK \& Prasad, GM 2016, 'Slope failure mechanism and monitoring techniques', Sensing and Monitoring Technologies for Mines and Hazardous Areas, Elsevier, Amsterdam.

Duncan, JM \& Wright, SG 2005, Soil Strength and Slope Stability, John Wiley \& Sons, Hoboken.

Hawley, M \& Cunning, J 2017, Guidelines for Mine Waste Dump and Stockpile Design, CSIRO Publishing: CRC Press, London.

Liu, SY, Shao, LT \& Li, HJ 2015, 'Slope stability analysis using the limit equilibrium method and two finite element methods', Computers and Geotechnics, vol. 63, pp. 291-298, https://doi.org/10.1016/j.compgeo.2014.10.008

Memon, Y 2018, 'A comparison between limit equilibrium and finite element methods for slope stability analysis', Missouri University of Science and Technology, Rolla, https://doi.org/10.13140/rg.2.2.16932.53124

Saeedi, M, Li, LY, Karbassi, AR \& Zanjani, AJ 2013, 'Sorbed metals fractionation and risk assessment of release in river sediment and particulate matter', Environmental Monitoring and Assessment, vol. 185, pp. 1737-1754, https://doi.org/10.1007/s10661012-2664-3

Sakurai, S 2017, Back-Analysis in Rock Engineering, CRC Press, London.

Sakurai, S, Farazmand, A \& Adachi, K 2009, 'Assessment of the stability of slopes from surface displacements measured by GPS in an open pit mine', Proceedings of the Third International Seminar ECOMINING-Europe 21st Century, University of Petrosani, Petrosani, pp. 239-248.

Simmons, JV \& McManus, DA 2004, 'Shear Strength Framework for Design of Dumped Spoil Slopes for Open Pit Coal Mines', Advances in Geotechnical Engineering: The Skempton Conference, Institute of Civil Engineers, London.

Zhang, C, Yu, Z, Zeng, G, Jiang, M, Yang, Z, Cui, F, ... \& Hu, L 2014, 'Effects of sediment geochemical properties on heavy metal bioavailability', Environment International, vol. 73, pp. 270-281, https://doi.org/10.1016/j.envint.2014.08.010 